\title{
PENGARUH BELANJA DAERAH INVESTASI DAN KURS TERHADAP PERTUMBUHAN EKONOMI DKI JAKARTA PERIODE 1987 - 2017
}

\author{
Yurianto \\ Widyaiswara Ahli Madya \\ Email: yurimerdeka@gmail.com \\ Diterima: 28 Februari; Direvisi: 27 Maret 2020; dipublikasikan: 30 April 2020
}

\begin{abstract}
Jakarta's economic growth plays an important role in the national economy. For this reason, it is necessary to identify the factors that influence the Jakarta's economic growth. The purpose of this study is to describe the development of economic growth, investment, the exchange rate of the rupiah against the US dollar and the allocation of regional spending and analyze the effect of regional spending, investment, exchange rates, economic crisis on the Jakarta's economic growth period 1987-2017. The analysis method is quantitative and descriptive qualitative methods. The results of the analysis, the coefficient of determination ( $R 2)$ reaches 0.912 . The ratio of goods, services and capital expenditure to total expenditure and investment has a positive and significant effect on economic growth while the depreciation of the rupiah against the United States dollar and the economic crisis have a negative impact.
\end{abstract}

Keyword : economic growth, investment, exchange rate, spending

\begin{abstract}
ABSTRAK
Pertumbuhan ekonomi Jakarta berperan penting dalam perekonomian nasional. Untuk itu perlu diidentifikasi faktor-faktor apa yang mempengaruhinya. Tujuan kajian ini mendeskripsikan perkembangan pertumbuhan ekonomi, investasi, nilai tukar rupiah terhadap dollar Amerika Serikat dan alokasi belanja daerah serta menganalisis pengaruh belanja daerah, investasi, kurs, krisis ekonomi terhadap Pertumbuhan Ekonomi Jakarta periode 1987-2017. Metode analisisnya adalah metode kuantitatif dan deskriptif kualitatif.. Hasil analisis, koefisien determinasi (R2) mencapai 0,912. Rasio belanja barang, jasa dan modal terhadap total belanja serta investasi berpengaruh secara positif dan signifikan terhadap pertumbuhan ekonomi sedangkan depresiasi nilai tukar rupiah terhadap dollar Amerika Serikat dan krisis ekonomi berpengaruh negatif.
\end{abstract}

Kata Kunci : pertumbuhan ekonomi, investasi, nilai tukar, belanja 


\section{PENDAHULUAN}

Jakarta mempunyai peran yang sangat penting dalam perekonomian nasional. Kontribusi perekonomian Jakarta dalam lingkup nasional mencapai 16-17 persen dari total PDB nasional. Sumbangan ini merupakan kontribusi tertinggi dibanding provinsi lain. Hal ini menjadikan pertumbuhan dan pembangunan perekonomian Jakarta mendapat perhatian berkaitan dengan pengembangan perekonomian nasional. Dengan kata lain, pertumbuhan ekonomi Jakarta yang stabil, berkelanjutan, berkembang dan berketahanan sangat dibutuhkan guna mendukung perekonomian Nasional.

Pertumbuhan ekonomi Jakarta detentukan faktor teknis ekonomis maupun non-teknis ekonomis. Faktor-faktor ini selain dipengaruhi dinamkia perekembangan perekonomian global dan regional juga dipengaruhi oleh kebijakan Pemerintah Provinsi DKI Jakarta dan Pemerintah Pusat. Artinya untuk mendorong pertumbuhan ekonomi Jakarta dibutuhkan konvegensi kebijakan terutama kebijakan antara Pemerintah Provinsi DKI Jakarta, dunia usaha dan Pemerintah Pusat.

Secara konsep pertumbuhan ekonomi adalah proses kenaikan kapasitas produksi suatu perekonomian yang diwujudkan dalam bentuk kenaikan pendapatan nasional. Semakin tinggi tingkat pertumbuhan ekonomi maka semakin cepat proses pertambahan output suatu wilayah, sehingga prospek perkembangan wilayah semakin baik. Hal ini dapat diuraikan dengan pendekatan ekonomi.

Dalam konsep ekonomi, hal ini dapat didekati dari sisi permintaan dan sisi penawaran. Dari sisi permintaan agregat, maka peningkatan output domestik dapat diidentifikasi dengan empat komponen perekonomian, yaitu : pengeluaran konsumsi oleh rumahtangga (C), pengeluaran investasi oleh dunia bisnis dan rumahtangga (I), belanja pemerintah untuk barang dan jasa (G), dan nett eksport (X-M) (Dornbusch, Fischer dan Startz, 2004). Dalam kontek perekonomian daerah McCann (2006) memformulasikan hal ini dengan menggunakan konsep permintaan agregate standar dari Keynesian, dengan simbol $\mathrm{r}$ yang menandakan regional. Formula ini dideskripsikan sebagai : $\mathrm{Yr}=\mathrm{Cr}+\mathrm{Ir}+\mathrm{Gr}+\mathrm{Xr}-\mathrm{Mr}$

Dengan formula tersebut faktor belanja daerah dan investasi berpengaruh langsung terhadap pertumbuhan ekonomi. Dalam hal investasi, Boediono (1992) mengatakan bahwa investasi adalah pengeluaran oleh sektor produsen (swasta) untuk pembelian barang dan jasa untuk menambah stok yang digunakan atau untuk perluasan pabrik. Dengan demikian maka investasi akan menimbulkan multiplier effect yang signifikan bagi perekonomian. Dengan kata lain investasi swasta berdampak positif tehadap pertumbuhan ekonomi (Huang, 2009).

Hasil penelitian tentang pertumbuhan ekonomi daerah di era otonomi daerah bahwa investasi dan belanja daerah mempengaruhi pertumbuhan ekonomi. Menurut Ahmad. F (2016) belanja modal tidak memiliki pengaruh yang signifikan dalam meningkatkan pertumbuhan ekonomi provinsi-provinsi di Sumatera. Dalam kontek ini penelitian Wahyuni dkk (2014)) menyatakan bahwa pengeluaran pemerintah dan investasi berpengaruh positif dan signifikan terhadap pertumbuhan ekonomi di Kabupaten/Kota di Provinsi Bali.

Dalam hal investasi menurut Purnamasari dkk.(2017) meningkatnya nilai investasi di Provinsi Sulawesi Tenggara meningkatkan pertumbuhan ekonomi. Hasil penelitian Putri, P I (2014) menyatakan investasi domestik, pengeluaran modal, tenaga kerja dan infrastruktur berpengaruh positif secara signifikan terhadap pertumbuhan ekonomi di Pulau Jawa. Penemuan sebelumnya diperkuat oleh penelitian Wahyudin D dan Imamudin Y. (2013) peningkatan investasi satu persen investasi meningkatkan pertumbuhan ekonomi di setiap Kabupaten/Kota di DIY sebesar 0,10. Ini menunjukkan bahwa pertumbuhan ekonomi dipengaruhi oleh alokasi belanja daerah dan investasi pada suatu daerah. Penelitian Calderon et al. (2004) menyimpulkan bahwa investasi untuk pembangunan infrastruktur memiliki pengaruh positif yang signifikan terhadap pertumbuhan ekonomi jangka panjang. 
Bagi daerah seperti Jakarta sebagai Ibukota Negara Kesatuan Republik Indonesia dan merupakan pusat kegiatan bisnis dan keuangan internasional, maka pertumbuhan ekonomi dipengaruhi juga oleh factor yang berskala internasional, regional dan nasional, yaitu nilai tukar rupiah terhadap dollar Amerika Serikat. Hal ini seperti temuan Ismanto dkk (2019) bahwa variabel kurs memiliki pengaruh yang signifikan terhadap pertumbuhan ekonomi.

Dalam hal fenomena ekonomi Mubyarto (2001) mengemukakan bahwa salah satu gejala atau sifat sistem ekonomi pasar adalah adanya siklus atau "konjungtur" kegiatan ekonomi, baik siklus jangka pendek, jangka menengah, maupun jangka panjang. Yang terjadi di Indonesia adalah siklus ekonomi terjadi dengan periodisasi 7 tahunan sejak Indonesia merdeka sampai tahun 2001. Sejalan dengan hal ini, fenomena krisis ekonomi yang terjadi mulai Agustus tahun 1997 merupakan cobaan serius dalam sejarah perekonomian Indonesia termasuk Jakarta. Hal inilah juga yang mendasari variabel krisis dimasukan dalam analisis pertumbuhan ekonomi Jakarta.

Dengan mendasarkan pada uraian di atas, maka pertumbuhan ekonomi Jakarta menjadi isu penting dan strategis bagi perekonomian nasional, oleh karena itu, diperlukan kajian yang komprehensif untuk mengidentifikasi determinan pertumbuhan ekonomi Jakarta. Dengan mendasarkan pada variabel variabel yang telah disebutkan di atas dan perkembangan hasil penelitian yang bersesuaian serta kondisi krisis ekonomi maka pertumbuhan ekonomi Jakarta dalam hal ini diduga dipengaruhi oleh nilai investasi, jumlah alokasi belanja daerah, kurs nilai tukar rupiah terhadap dolar Amerika Serikat serta kondisi krisis ekonomi sebagai variabel dummy.

Dalam kontek ini pertanyaan pertama kajian ini adalah bagaimana karakter dan perkembangan pertumbuhan ekonomi, investasi, nilai tukar rupiah terhadap dollar Amerika Serikat dan alokasi belanja daerah dalam APBD Provinsi DKI Jakarta. Pertanyaan kedua adalah sampai berapa besar pengaruh faktor- faktor tersebut terhadap pertumbuhan ekonomi Jakarta. Sejalan dengan ini maka tujuan kajian ini adalah sebagai berikut.

1. Mendeskripsikan perkembangan pertumbuhan ekonomi, investasi, nilai tukar rupiah terhadap US dollar dan alokasi belanja daerah dalam APBD Provinsi DKI Jakarta .

2. Menganalisis pengaruh belanja daerah, investasi, Kurs, dan krisis ekonomi terhadap Pertumbuhan Ekonomi DKI Jakarta Periode 1987 - 2017.

\section{METODE}

Implementasi kebijakan otonomi daerah yang didasarkan pada Undang-undang No 23 tahun 2014 tentang Pemerintahan Daerah dan Undang-undang No 33 tahun 2004 tentang Perimbangan Keuangan antara Pemerintah Pusat dan Pemerintahan Daerah membawa pengaruh tersendiri terhadap perekonomian Jakarta. Hal ini dapat dikerangkakan sebagai berikut.

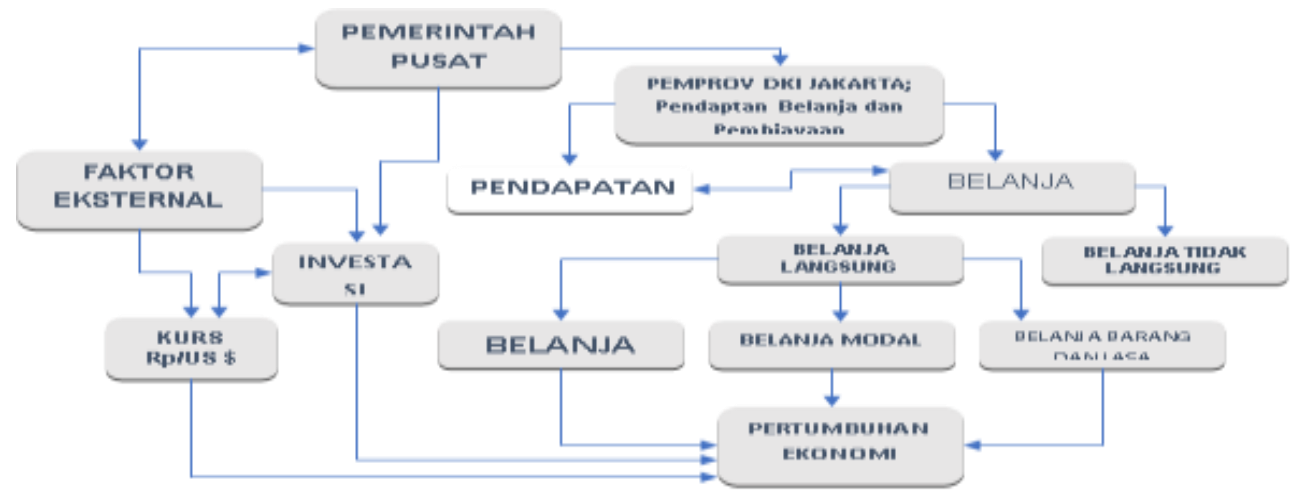

Gambar 1. Kerangka Pemikiran 


\section{sosio e-kons}

Volume 12, No. 1, April 2020, pp. 31-43

e-ISSN: 2502-5449

p-ISSN: 2085-2266

DOI : 10.30998/sosioekons.v12i1.5946

Pada Gambar 1 menjelaskan kerangka pikir kajian tentang determinan pertumbuhan ekonomi DKI Jakarta. Pada kebijakan desentralisai fiksal dan otonomi daerah, Pemerintah Provinsi DKI Jakarta mempunyai kewenangan yang lebih luas dibanding sebelumnya. Kelompok belanja tidak langsung merupakan belanja yang dianggarkan tidak terkait secara langsung dengan pelaksanaan program dan kegiatan. Sedangkan Kelompok belanja langsung merupakan belanja yang dianggarkan terkait secara langsung dengan pelaksanaan program dan kegiatan.

Kelompok belanja langsung dibagi menurut jenis belanja yang terdiri dari belanja pegawai, belanja barang dan jasa, dan belanja modal. Sedangkan belanja modal adalah belanja yang digunakan untuk pengeluaran yang dilakukan dalam rangka pembelian/pengadaan atau pembangunan aset tetap berwujud yang mempunyai nilai manfaat lebih dari 12 (duabelas) bulan.

Namun perlu menjadi catatan bahwa investasi dan nilai tukar juga saling mempengaruhi. Hal ini ditunjukkan oleh hasil penelitian Febrian dan Muqorobbin (2014) bahwa ada pengaruh tingkat nilai tukar rupiah terhadap dolar AS terhadap investasi asing langsung dalam jangka pendek menunjukkan tanda positif dan signifikan. Sedangkan penelitian Istiqomah (2013) menemukan bahwa investasi asing berpengaruh positif terhadap nilai tukar rupiah per dollar AS.

Dalam penelitian ini analisis data dilakukan dengan analisis regresi berganda. Analisis regresi berganda digunakan untuk mengidentifikasi variabel-variabel yang mempengaruhi pertumbuhan ekonomi di DKI Jakarta. Software yang digunakan dalam penelitian ini adalah Software SPSS Versi 16. Metode analisis deskriptif digunakan untuk menggambarkan secara umum keragaan belanja daerah, pertumbuhan ekonomi, laju investasi, perkembangan nilai tukar dan karakteristik kondisi ekonomi lainnya yang berkaitan dengan kajian ini. Data yang digunakan dalam penelitian ini adalah data sekunder yang diperoleh dari berbagai sumber. Penelitian ini menggunakan data series untuk periode tahun 1987-2017.

Data yang digunakan dalam hal ini meliputi variabel-variabel sebagai berikut:

1. Pertumbuhan ekonomi adalah nilai kenaikan output/perubahan nilai riil berdasarkan PDRB Provinsi DKI Jakarta atas dasar harga kosntan, dalam persen.

2. Rasio belanja barang modal yang dimaksud dalam peneltiian ini adalah rasio alokasi belanja langsung yang terdiri dari belanja modal dan belanja barang dan jasa terhadap total belanja, yaitu belanja langsung dan belanja tidak langsung Pemerintah Provinsi DKI Jakarta.

3. Nilai investasi dalam penelitian ini didekati dengan nilai pembentukan modal tetap bruto (PMTB).

4. Nilai kurs adalah nilai tukar mata uang rupiah terhadap dollar Amerika Serikat.

5. Dummy variabel juga digunakan dalam penelitian ini untuk menggambarkan dampak krisis ekonomi yang melanda Indonesia pada tahun 1998.

Untuk memperoleh variabel pendugaan yang tepat diperlukan spesifikasi yang tepat dan dapat dipertanggungjawabkan secara teori (Hardani, Priska Rialita; Abdul Hoyyi, dan Sudarno, 2016. Dalam penelitian ini model yang diajukan untuk mengetahui variabel-variabel yang mempengaruhi pertumbuhan ekonomi di DKI Jakarta adalah sebagai berikut:

dimana

$$
P E R T \_E K_{t}=\beta_{0}+\beta_{1} R M D L_{1 t}+\beta_{2} I N V_{2 t}+\beta_{3} K U R S_{3 t}+\beta_{4} D_{98}+u_{t}
$$

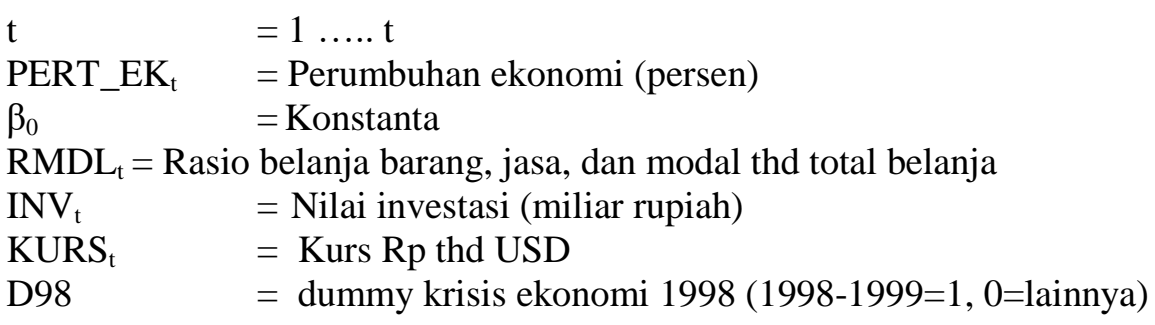




\section{Uji Asumsi}

Untuk mendapatkan model yang baik, selain uji statistik seperti dijelaskan pada bagian sebelumnya, juga dilakukan uji asumsi klasik. Uji asumsi klasik yang akan dilakukan dalam penelitian ini meliputi uji normalitas, uji multikolinieritas, uji homoskedastisitas dan uji autokorelasi.

\section{Uji Keberartian Model}

Menurut Gujarati (1995) dalam pengujian model perlu dilakukan dengan cara melihat koefisien determinasi $\left(\mathrm{R}^{2}\right.$ ), overall test (uji $\mathrm{F}$ ), dan partial test (uji $t$ ). Nilai $\mathrm{R}^{2}$ menunjukan berapa besar variasei dari semua variabel bebas dapat menjelaskan varaibel tidak bebasnya. Dalam hal ini seberapa besar variasi varabel rasio belanja barang dan modal, nilai investasi, dan nilai tukar rupiah terhadap dollar Amerika Serikat dapat menjelaskan variasi pertumbuhan ekonomi di DKI Jakarta.

Selanjutnya untuk mengetahui pengaruh variabel independent secara bersama sama digunakan uji $\mathrm{F}$ (F test). Uji $\mathrm{F}$ digunakan untuk melihat bagaimana pengaruh semua variabel bebas terhadap variabel terikat dan untuk menguji apakah model regresi yang ada signifikan atau tidak signifikan. Sementara uji t statistik untuk menguji bagaimana pengaruh masingmasingvariabel bebasnya terhadap variabel terikatnya.

\section{HASIL DAN PEMBAHASAN}

\section{Kinerja Perekonomian DKI Jakarta}

Pembangunan di DKI Jakarta selama ini menunjukkan hasil yang menggembirakan yang ditandai dengan membaiknya berbagai indikator pembangunan. Pada Gambar 2 pertumbuhan ekonomi DKI Jakarta sebelum krisis ekonomi pada pertengahan 1997 cukup tinggi antara 6-10 persen. Pada saat terjadi krisis ekonomi pada tahun 1998 pertumbuhan ekonomi terkoreksi cukup dalam pada tahun 1998 yang mencapai minus 17,49 persen. Sementara sejak tahun 2000 pertumbuhan perekonomian relatif stabil di sekitar 5 persen.

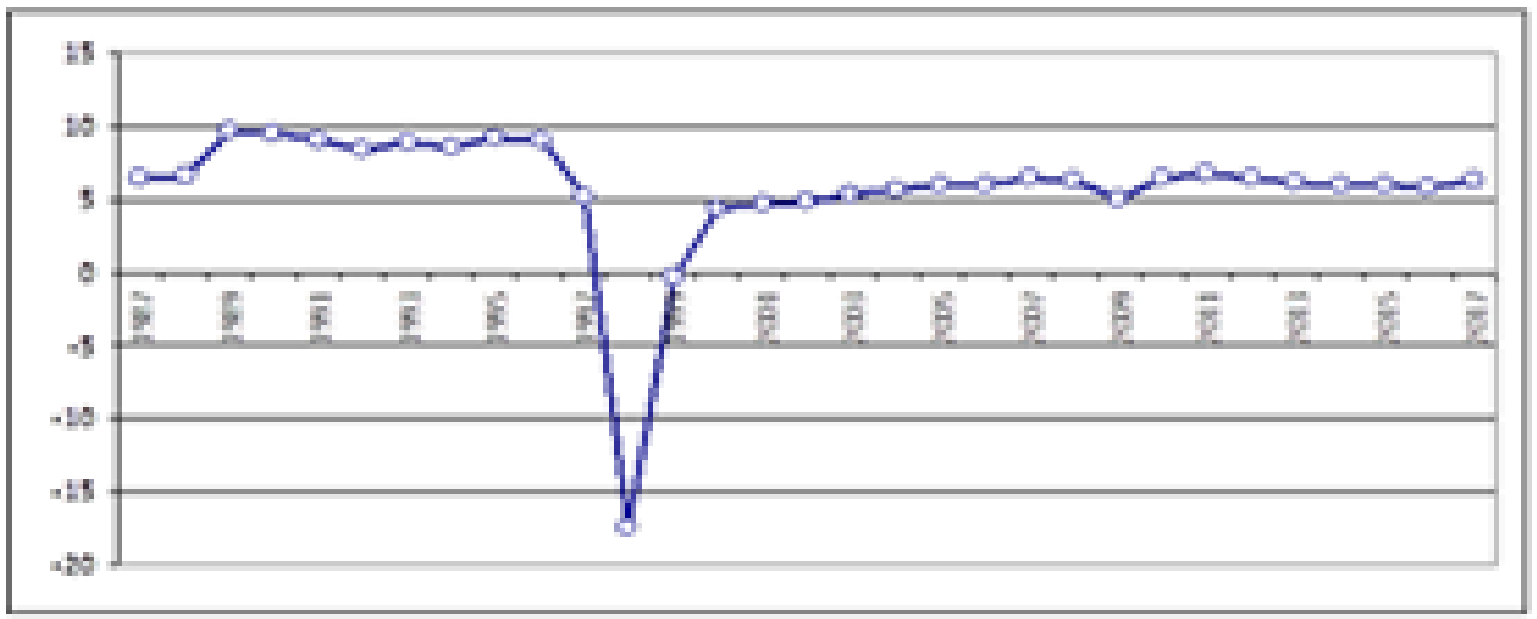

Gambar 2. Pertumbuhan Ekonomi DKI Jakarta, 1987-2017. Sumber BPS, Beberapa Tahun

Pertumbuhan ekonomi DKI Jakarta selalu di atas rata-rata pertumbuhan ekonomi nasional. Ini terjadi karena DKI Jakarta merupakan salah satu penggerak perekonomian nasional. Selain sebagai Ibukota Negara Kesatuan Republik Indonesia, DKI Jakarta merupakan pusat perekonomian dan keuangan di Indonesia. Pertumbuhan ekonomi ini akan berdampak pada membaiknya pendapatan masyarakat yang ditandai dengan kenaikan PDRB per kapita. Namun demikian, perekonomian di DKI Jakarta sensitive terhadap kebijakan pemerintah maupun guncangan dari luar. Ini dapat dilihat ketika krisis ekonomi tahun 1997-1999 dan krisis 
finansial dunia tahun 2008-2009 pertumbuhan ekonomi DKI Jakarta langsung terkoreksi. Hal ini tergambar pada Gambar.2.

Hal ini sejalan dengan pendapat Perroux (2007) dalam Adisasmita (2008), bahwa suatu lokasi dapat dikatakan sebagai kutub pertumbuhan apabila di tempat tersebut terdapat industri kunci (key industry). Argumennya adalah bahwa Industri kunci ini berperan penting sebagai pendorong yang dinamik, karena industri tersebut mempunyai kemampuan untuk melakukan inovasi. Wilayah yang mempunyai industri kunci yang tumbuh dengan baik, maka industri tersebut merupakan kutub pertumbuhan.

Dengan demikian, dapat dikatakan bahwa industri kunci dalam suatu wilayah, juga sangat menentukan aktivitas perekonomian. Selanjutnya Perroux (2007) dalam Adisasmita (2008) menyebutkan ada tiga ciri penting dalam konsep titik pertumbuhan, yaitu : (1) terdapat keterkaitan internal antara berbagai industri secara teknik dan ekonomi, (2) terdapat pengaruh multiplier, dan (3) terdapat konsentrasi geografis.

Dalam hal petumbuhan ekonomi menurut pendapat Todaro dan Smith (2006) bahwa pertumbuhan ekonomi negara atau wilayah sangat tergantung dari tingkat akumulasi modal yang meliputi semua bentuk atau jenis investasi baru yang dialokasikan dalam perekonomian. Artinya semakin tinggi akumulasi pengeluaran pemeirntah daerah semakin tinggi tingkat pertumbuhan ekonomi dan semakin tinggi tingkat kesejahteraan masyarakatnya.

\section{Belanja Pemerintah Provinsi DKI Jakarta}

Berbeda dengan era sebelumnya bahwa pada era otonomi daerah, yatu pasca 1998 bahwa kebijakan alokasi belanja ini diperoleh melalui proses pelibatan seluruh pemangku kepentingan pembangunan, yaitu pemerintah, masyarakat, dan dunia usaha. Prosesnya pelibatan ini dilalui dengan cara proses politik, teknokratik, partisipatif, top down dan bottom up (Undang-undang Nomor 25 Tahun 2004). Hal ini didasarkan karena kebijakan pengeluaran pemerintah merupakan kebijakan publik yang secara langsung mempengaruhi kepentingan masyarakat.

Untuk memenuhi kebutuhan pembangunan daerah diperlukan dana yang relatif besar. Kebijakan pemerintah daerah untuk pembangunan daerah direpresentasikan oleh besarnya alokasi belanja daerah. Dalam hal belanja daerah bahwa pendapat Rostow dan Musgrave dalam Mangkusoebroto (1998) bahwa pada tahap awal perkembangan ekonomi alokasi belanja yang utama adalah menyediakan prasarana seperti pendidikan, kesehatan, prasarana transportasi dan sebagainya.

Dalam pembangunan daerah dibutuhkan belanja yang cukup besar. Besarnya belanja pembangunan baik belanja langsung maupun belanja tidak langsung sangat tergantung dari besarnya tingkat pendapatan daerah. Berdasarkan data empiris bahwa jumlah belanja Pemerintah Provinsi DKI Jakarta cenderung terus meningkat dan peningkatan ini cukup signifikan. Peningkatan ini dikarenakan jumlah pendapatan daerah cenderung meningkat. Peningkatan alokasi belanja daerah secara rinci, seperti terlihat pada Gambar 3.

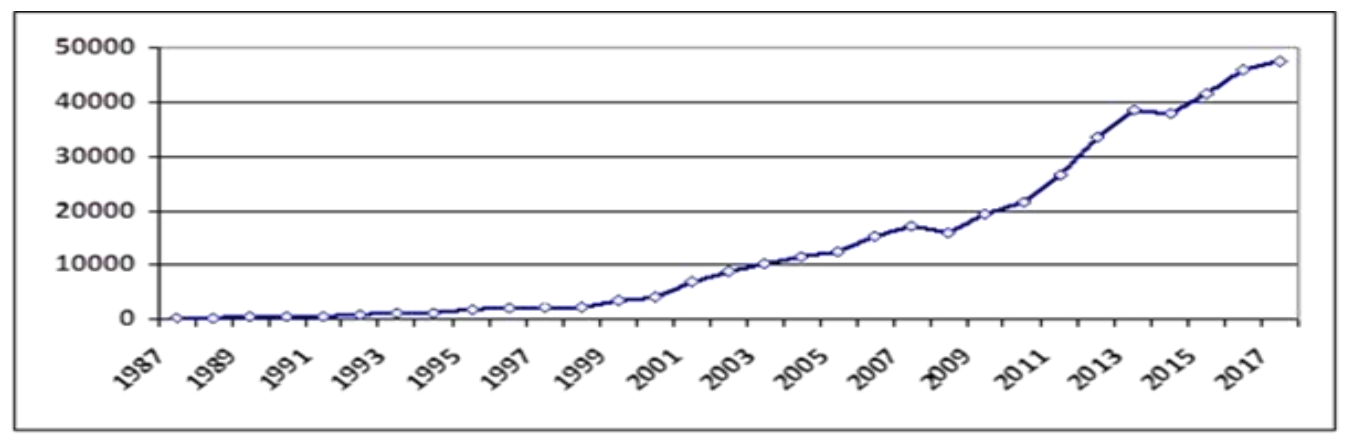

Gambar 3 Perkembangan Belanja Pemerintah Provinsi DKI Jakarta, 1987-2017 
Volume 12, No. 1, April 2020, pp. 31-43

e-ISSN: 2502-5449

p-ISSN: 2085-2266

DOI : 10.30998/sosioekons.v12i1.5946

Pada Gambar 3 dapat dilihat bahwa pada periode 1987-2017 belanja Pemerintah Provinsi DKI Jakarta terus mengalami kenaikan, kecuali pada tahun 2008 dan 2014. Ini menunjukkan kemampuan keuangan Pemerintah Provinsi DKI Jakarta cenderung meningkat. Mengingat belanja daerah terdiri belanja langsung dan belanja tidak langsung, dan belanja langsung terdiri dari belanja pegawai, belanja barang dan jasa serta belanja modal maka untuk melihat proporsi perlu dilihat perbandingan tersebut. Gambar 4. menggambarkan porporsi antar jenis belanja langsung tersebut.

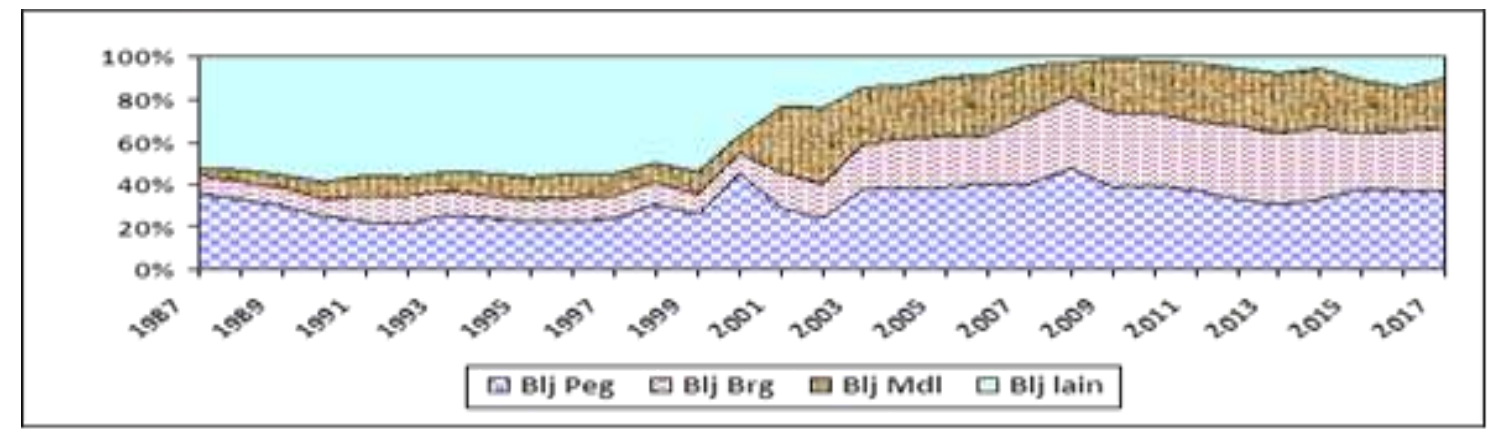

Gambar 4. Perkembangan Belanja Pemerintah Provinsi DKI Jakarta Menurut Jenis Belanja, 1987-2017

Dengan mendasarkan pada Gambar 4 bahwa apabila dilihat menurut jenis belanjanya, terlihat terjadi perubahan drastis pada alokasi belanja Pemerintah Provinsi DKI Jakarta sejak tahun 2002. Untuk belanja pegawai relatif stabil sekitar 30-40 persen dari total belanja. Perubahan drastis terjadi pada belanja barang dan jasa serta belanja modal.

Sebelum tahun 2002, belanja lainnya memiliki porsi terbesar dalam alokasi belanja Pemprov DKI Jakarta. Namun sejak tahun 2002, belanja barang dan jasa serta belanja modal mengalami peningkatan tajam. Baik belanja barang dan jasa maupun belanja modal mempunyai porsi masing-masing sekitar 20 persen dari total belanja. Sementara untuk belanja lainnya hanya mempunyai alokasi sekitar 10 persen dari total belanja.

\section{Pergerakan Nilai Tukar Rupiah Terhadap Dollar Amerika}

Penyebab terjadinya fluktuasi nilai tukar rupiah terhadap dollar berasal dari berbagai faktor baik yang teknis ekonomi maupun non teknis. Faktor-faktor tersebut antara lain jumlah uang beredar, harga, suku bunga, kondisi politik, kebijakan pemerintah, isu pembangunan dan lain-lain. Nilai tukar Indonesia periode 1987-2017 juga mengalami fluktuasi yang sangat dinamis. Gambar berikut memberikan informasi perkembangan nilai tukar rupiah terhadap dollar Amerika.

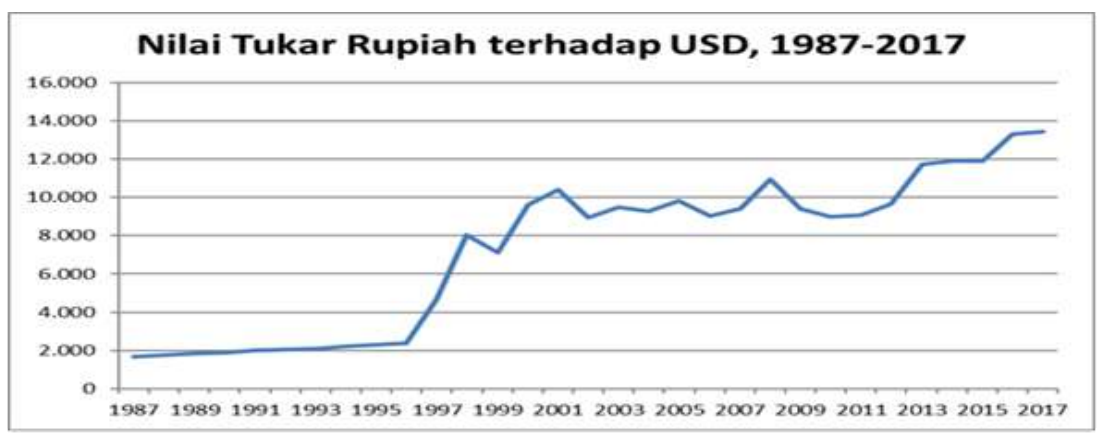

Gambar 5. Nilai Tukar Rupiah terhadap USD 1987-2017

Berdasarkan Gambar 5 di atas, nilai kurs rupiah terhadap US dollar cenderung terdepresiasi. Data empiris di atas menunjukkan bahwa sebelum tahun 1992 nilai tukar rupiah 
terhadap dollar Amerika Serikat masih di bawah 2.000 rupiah. Tahun 1987 nilai tukar rupiah per dollar Amerika Serikat hanya 1.661,7 dan tahun 1991 nilai tukar hanya 1.992 tahun 1992 sudah mendekati angka 2000 rupiah, yaitu 2.062 rupiah. Sejak krisis moneter mulai tahun 1993 nilai rupiah terus mengalami depresiasi dan nilai kurs stabil berkisar antara 13.000 sampai 14.000 rupiah per dollar Amerika Serikat.

\section{Pergerakan Nilai Investasi di Jakarta}

Dalam penelitian ini, untuk variable jumlah investasi di Jakarta digunakan dengan pendekatan nilai Pembentukan Modal Tetap Bruto (PMTB). Investasi merupakan faktor yang mempengaruhi peningkatan output domestik atau pertumbuhan ekonomi. Untuk itulah, pemerintah daerah selalu berusaha untuk menarik investor untuk bersedian menanamkan investasinya. Dalam hal ini laju investasi Jakarta dapat diuraikan pada Gambar 6 berikut.

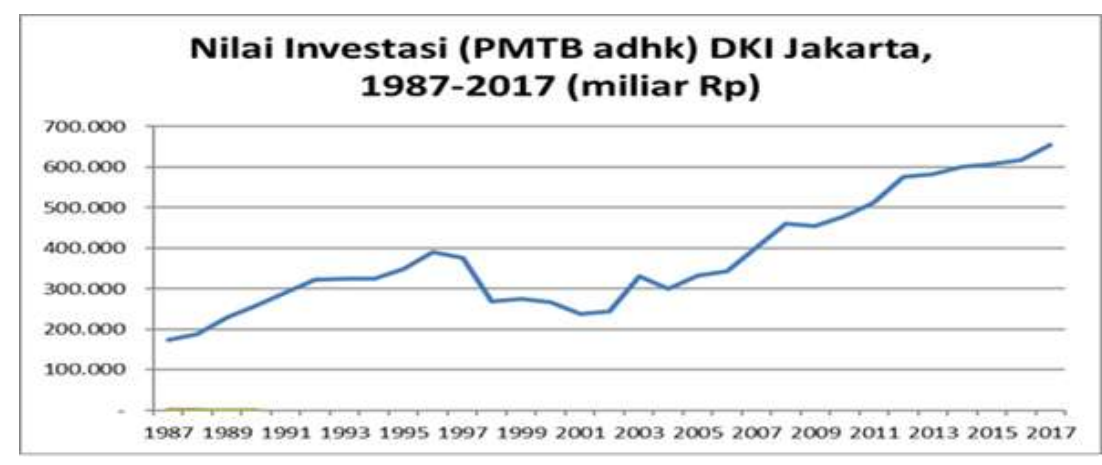

Gambar 6. Nilai Investasi di Jakarta Periode 1987-2017

Berdasarkan Gambar 6 terlihat bahwa pertumbuhan nilai investasi di DKI Jakarta mengalami peningkatan yang cukup signiifkan. Ini menunjukan bahwa iklim investasi di DKI Jakarta sangat kondusif secara teori maka dengan investasi yang meningkat pertumbuhan ekonomi juga meningkat. Pada tahun 1987 nilai investasi hanya 173, 31 trlliun rupiah dan meningkat menjadi 391,1 triliun rupiah pada tahun 1996.Periode 1997 - 2002 jumlah investasi menurun. Pada tahun 2002 investasi Jakarta hanya mencapai 243, 18 trliun rupiah.Setelahnya investasi terus meningkat dan pada tahun 2017 investasi mencapi 654,59 triliun rupiah.

Peningkatan investasi dipengaruhi oleh berbagai faktor. Menurut Gottheil (1996), Sodik dan Nuryadin (2008) bahwa investasi swasta sangat dipengaruhai oleh PDRB, kondisi infrastruktur, keterbukaan ekonomi, tingkat perkembangan teknologi, tingkat suku bunga, ekspektasi pertumbuhan ekonomi di masa yang akan datang, dan tingkat kapasitas produksi.

Namun yang perlu mendapat perhatian adalah hasil penelitian Hasan dan Purwanto (2005). Menurut penelitian ini Indonesia termasuk negara di Asia yang iklim investasinya tidak sehat dan tidak kompetitif serta pertumbuhan ekonominya yang lamban. Disampaikan pada penelitian ini bahwa penyebab kondisi ini adalah kualitas sumber daya manusianya yang rendah, daya saing perekonomiannya rendah, dan tingkat pengangguran yang tinggi.

\section{Faktor-faktor yang Mempengaruhi Pertumbuhan Ekonomi DKI Jakarta}

Determinan pertumbuhan ekonomi DKI Jakarta sangat variative baik yang sifatnya teknis-ekonomis maupun non teknis. Dalam kajian ini determinan pertumbuhan ekonomi didekati dengan factor ekonomi, yaitu rasio belanja daerah, nilai investasi dan nilai tukar rupiah terhadap dollar Amerika Serikat.

Rasio belanja didekati dengan formula dengan rasio belanja antara jumlah belanja barang dan jasa, ditambah belanja modal terhadap total belanja $\left(\mathrm{RMDL}_{\mathrm{t}}\right)$. Nilai investasi dalam 
hal ini didekati dengan nilai Pembentukan Modal Tetap Bruto (PMTB) dan )selanjutnya dilambngkan dengan $\mathrm{INV}_{\mathrm{t}}$ (Nilai investasi dalam miliar rupiah). Selanjutnya nilai tukar rupiah terhadap dollar Amerika Serikat yang pada prinsipnya adalah nilai rupiah per 1 dollar Amerika Serikat $\left(\mathrm{KURS}_{\mathrm{t}}\right)$. Selanjutnya untuk melihat pengharuh krisis ekonomi tahun 1998 didekati dengan variable Dummy (D98). Dalam hal ini digunakan untuk tahun 1998-1999=1 sementara selain tahun tersebut $=0$.

Untuk mengetahui determinan yang berpengaruh terhadap pertumbuhan ekonomi di DKI Jakarta digunakan analisis regresi berganda dengan menggunaka software SPSS Versi 16. Adapun hasilnya adalah sebagai berikut.

PERT_EK $=6,448+0,049 R M D L_{t}{ }^{*}+0,00000721 I N V_{t}^{* *}-0,001 K U R S_{t}{ }^{* *}-21,732 D 98 * *$ $R^{2}$-adj $=0,912 \quad D W=1,942 \quad F$-sig $=0,000$

** signifikan pada $\alpha 5 \%$ * signifikan pada $\alpha 10 \%$

Hasil estimasi tersebut selanjutnya dilakukan pengujian berdasarkan kriteria ekonomi, statistik dan ekonometrika. Berdasarkan kriteria ekonomi, hasil estimasi parameter persamaan tersebut sesuai secara teori dan dapat dipertanggungjawabkan. Hal ini ditunjukkan dengan tanda dan besaran nilai estimasi parameter yang menggambarkan hubungan antara variabel dependen dengan variabel-variabel independent yang merupakan variabel penjelas.

Selanjutnya digunakan kriteria statistik untuk menguji persamaan yang telah disusun. Nilai koefisien determinasi $\left(R^{2}\right)$ dari persamaan yang disusun cukup tinggi yaitu 0,912 . Ini menunjukkan bahwa variabel-variabel penjelas (RMDL, INV, KURS, dan D98) yang digunakan dalam persamaan tersebut 91,2 persen dapat menjelaskan keragaman variabel pertumbuhan ekonomi di DKI Jakarta.

Sementara probabilita statistik uji-F yang dihasilkan untuk menguji apakah variabelvariabel penjelas yang digunakan berpengaruh nyata terhadap variabel dependennya bernilai 0,000. Ini berarti variabel-variabel penjelas yang digunakan dalam model secara bersama-sama berpengaruh nyata terhadap pertumbuhan ekonomi di DKI Jakarta.

Uji parsial setiap variabel menggunakan statistik uji-t untuk menguji apakah suatu variabel penjelas secara individu berpengaruh terhadap variabel dependennya atau tidak. Hasil estimasi menunjukkan bahwa pada tingkat signifikansi 5 persen variabel nilai investasi, nilai tukar rupiah terhadap dollar Amerika Serikat dan krisis ekonomi 1998 signifikan berpengaruh terhadap pertumbuhan ekonomi di DKI Jakarta. Sementara rasio belanja barang dan modal signifikan mempengaruhi pertumbuhan ekonomi pada tingkat signifikansi 10 persen.

Selain itu juga dilakukan uji asumsi klasik untuk mendapatkan model yang baik. Uji asumsi tersebut meliputi uji normalitas, uji multikolinieritas, uji homoskedastisitas dan uji autokorelasi. Hasil uji-uji tersebut menunjukkan model yang dihasilkan dapat diterima dan sesuai dengan asumsi-asumsi secara teroritis.

\section{Interpretasi Model}

Langkah selanjutnya dalam hal ini adalah penjelasan dan interpretasi model sebagaimana telah diuraikan di atas. Hasil analisis yang di representasikan dengan model dan hasil perhitungan adalah sebagai berikut.:

PERT_EK $=6,448+0,049 R_{t} M D L_{t}^{*}+0,00000721 I N V_{t}^{* *}-0,001 \mathrm{KURS}_{t}^{* *}-21,732 \mathrm{D} 98$ **

Dalam hal ini variabel rasio belanja barang dan jasa dan modal terhadap total belanja dalam analisis mempunyai koefisien 0,049 dan hubungannya positif serta mempunyai signifikansi $\alpha 10$ persen. Ini mempunyai pengertian bahwa hubungan positif RMDL terhadap pertumbuhan ekonomi di DKI Jakarta. Nilai koefisien 0,049 menunjukkan bahwa peningkatan RMDL sebesar 1 persen cateris paribus, akan meningkatkan laju pertumbuhan ekonomi di DKI Jakarta sebesar 0,049 persen.

Dalam hal ini Akhmad (2015) menyatakan bahwa kebijakan alokasi belanja yang dilakukan oleh pemerintah daerah terutama belanja modal berpengaruh positif terhadap 
investasi swasta. Selain itu penelitian ini juga menunjukkan bahwa investasi swasta berpengaruh positif dan nyata terhadap pertumbuhan ekonomi, penyerapan tenaga kerja, dan penurunan tingkat kemiskinan. Penelitian Riyanto dan Siregar (2005) menunjukkan bahwa belanja rutin dan belanja pembangunan berpengaruh positif terhadap perekonomian daerah.

Variabel Investasi dan dalam hal ini koefisien variabel investasi (INV) didekati dengan nilai Pembentukan Modal Tetap Bruto (PMTB) mempunyai hubungan positif dan signifikan pada $\alpha 5$ persen. Kondisi ini mempunyai pengertian bahwa terdapat hubungan positif peningkatan investasi terhadap peningkatan pertumbuhan ekonomi. Nilai koefisien 0,00000721 menunjukkan bahwa peningkatan INV sebesar Rp 1 triliun cateris paribus, akan meningkatkan laju pertumbuhan ekonomi di DKI Jakarta sebesar 0,007 persen.

Hasil analisis variabel nilai tukar rupiah terhadap dollar Amerika Serikat (KURS) dalam analisis ini diperoleh hasil sesuai dengan konsep ekonomi. Koefisien variabel nilai tukar rupiah terhadap dollar Amerika Serikat (KURS) mempunyai tanda sesuai teori ekonomi, yaitu negatif dan signifikan pada $\alpha 5$ persen. Hal ini mempunyai pengertian bahwa terdapat hubungan negatif variabel nilai tukar rupiah terhadap dollar Amerika Serikat dengan peningkatan pertumbuhan ekonomi di DKI Jakarta dengan nilai koefisien sebesar 0,001. Artinya jika kurs rupiah terhadap dollar Amerika Serikat terdepresiasi 1 persen maka pertumbuhan ekonomi akan menurun sebesar 0,001 persen. Hal ini sejalan dengan hasil penelitian Suselo. Sihaloho dan Tarsidin (2008) bahwa volatilitas nilai tukar nominal dan nilai tukar riil yang negatif bagi pertumbuhan ekonomi.

Selanjutnya variabel krisis ekonomi tahun 1998 yang direpresentasikan dengan variabel dummy (D98) berpengaruh negative terhadap pertumbuhan ekonomi Jakarta. Dalam hal ini tingkat signifikansinya adalah a 5 persen. Dengan kata lain bahwa krisis ekonomi tahun 1998 yang dimulai di pertengahan 1997 dan puncaknya di 1998 berpengaruh negatif dan signifikan terhadap penurunan pertumbuhan ekonomi di DKI Jakarta.

\section{SIMPULAN}

Pertumbuhan ekonomi di DKI Jakarta pada periode 1987-2017 cenderung pada pergerakan yang positif. Namun karena krisis ekonomi yang dialami Indonesia yang terjadi dimulai pada tahun 1997 dan 1998 pertumbuhan ekonomi Jakarta terkoreksi cukup drastis.

Dari sisi belanja terjadi perubahan cukup signifikan dalam hal alokasi belanja sejak tahun 2002. Dalam hal ini belanja barang, jasa dan modal mempunyai alokasi yang cukup besar dan cenderung meningkat jika dibanding periode sebelumnya.

Pada periode 1987 sampai dengan 2017 nilai PMTB secara umum cenderung terus mengalami peningkatan yang signifikan. Jika tahun 1987 nilai investasi masih di bawah 200 triliun rupiah pada tahun 2017 sudah mencapai mencapi 654,59 triliun rupiah. Pada periode tahun 2003 - 2017 nilai investasi terus mengalami peningkatan.

Dalam hal nilai tukar rupiah terhadap dollar Amerika Serikat tahun 1987 nilai tukar rupiah per dollar Amerika Serikat hanya 1.661,7 rupiah per dollar Amerika Serikat dan tahun 1991 nilai tukar hanya 1.992 rupiah per dollar Amerika Serikat. Sejak tahun 1993 nilai rupiah terus mengalami depresiasi dan nilai kurs stabil berkisar antara 13.000 sampai 14.000 rupiah per dollar Amerika Serikat.

Rasio belanja barang, jasa dan modal terhadap total belanja Pemerintah Provinsi DKI Jakarta dan investasi berpengaruh secara positif dan signifikan terhadap pertumbuhan ekonomi di DKI Jakarta. Sementara depresiasi nilai tukar rupiah terhadap dollar Amerika Serikat berpengaruh negatif terhadap pertumbuhan ekonomi DKI Jakarta. Krisis ekonomi yang pernah melanda Indonesia yang puncaknya terjadi tahun 1998 juga berpengaruh negatif terhadap pertumbuhan ekonomi di DKI Jakarta. 


\section{SARAN}

Berkaitan dengan hal ini maka disarankan hasil penelitian ini diharapkan dapat menjadi bahan masukan dalam menyusun dokumen Rencana Kerja Pemerintah Daerah (RKPD) dan Kebijakan Umum APBD dan Prioritas Plafon Anggaran Sementara (KUA PPAS) bahwa alokasi belanja langsung dalam hal ini belanja modal dan belanja barang dan jasa berpengaruh positif terhadap pertumbuhan ekonomi Jakarta.

Bagi dunia akademik, mengingat faktor ekonomi yang mempengaruhi pertumbuhan ekonomi Jakarta cukup variatif selain yang telah dikaji dalam kaian ini maka disarankan untuk dilakukan penelitian lanjutan berkaitan dengan determinan pertumbuhan ekonomi Jakarta.

\section{DAFTAR RUJUKAN}

Adisasmita, R. (2008). Pengembangan Wilayah. Graha Ilmu, Edisi Pertama, Yogyakarta.

Ahmad, F.(2016). Pengaruh Belanja Modal terhadap Pertumbuhan Ekonomi Provinsi-provinsi di Sumatera. Journal e-Jurnal Perspektif Ekonomi dan Pembangunan Daerah. Volume 5 Issue 1 Pages 29-35

Akhmad. (2015). Dampak Pengeluaran Pemerintah Daerah terhadap Kemiskinan pada Sepuluh Kabupaten di Provinsi Sulawesi Selatan. Prosiding Seminar Nasional 2015 Lembaga Penelitian UNM Optimalisasi Hasil-Hasil Penelitian Dalam Menunjang Pembangunan Berkelanjutan ISSN:

Boediono. (1992). Ekonomi Makro. Edisi 4. Badan Penerbit Fakultas Ekonomi, Universitas Gajah Mada. Yogyakarta

Calderon, C. dan L. Serven. (2004). The Effects Of Infrastructure Development on Growth And Income Distribution. The World Bank, Paper WPS3400. The World Bank, April.

Dornbusch, R., S. Fischer and R. Startz. (2004). Macroeconomics. Ninth Edition. The McGrawHill Company, New York.

Febriana, A. dan Masyhudi M. (2014). Investasi Asing Langsung di Indonesia dan Faktor faktor yang Mempengaruhinya. Jurnal Ekonomi dan Studi Pembangunan Volume 15, Nomor 2, Oktober 2014, hlm.109-117

Gujarati, D.N. (1995). Basic Econometric. Mc.Graw Hill. New York.

Gottheil, Fred.M.G.(1996). Principles of Macroeconomics. University of Illinois, SouthWestern Collge Publishing, Ohio.

Hasan, M.F. dan D.A. Purwanto. (2005). Kebijakan Investasi Mendorong Pertumbuhan Ekonomi yang Adil dan Berkelanjutan. Jurnal Kebijakan Ekonomi, I (3): 217-234.

Huang, Y. (2009). Dynamic Panel Data Evidence on the Finance-Investment Link. Journal of Statistics : Advance in Theory and Applications, November (23): 1- 23.

Hardani, P. Rialita; A.Hoyyi, dan Sudarno. (2016). Peramalan Laju Inflasi, Suku Bunga ndonesia dan Indeks Harga Saham Gabungan Menggunakan Metode Vector Autoregressive (VAR). Jurnal GAUSSIAN, Volume 6, Nomor 1, Tahun 2016, Halaman 101-110.

Ismanto, B, Mita A K, Lelahester R. (2019). Pengaruh Kurs dan Impor Terhadap Pertumbuhan Ekonomi Indonesia Periode Tahun 2007-2017. Ecodunamika: Jurnal Pendidikan Ekonom. Vol 2 No 1 (2019) e-ISSN : 2614 - 803X.

Istiqomah, (2013). Pengaruh Inflasi dan Investasi terhadap Nilai Tukar Rupiah. Jurnal Signifikan Vol.2No. 1 April 2013. 57

Mangkoesoebroto, G. (1998). Ekonomi Publik Badan Penerbit Fakultas Ekonomi Universitas Gajah Mada, Yogyakarta.

McCann, P. (2006). Urban and Regional Economics. Oxford University Press, New York. 
Mubyarto, (2001). Siklus Tujuh Tahunan Ekonomi Indonesia Jurnal Ekonomi dan Bisnis Indonesia Vol. 16, No. 3, 2001, 246 - 260 (1931-1966-2001-2036).

Putri, P. I. (2014). Pengaruh Investasi, Tenaga Kerja, Belanja Modal, dan Infrastruktur terhadap Pertumbuhan Ekonomi Pulau Jawa. JEJAK Journal of Economics and Policy. Vol 7 (2) hal. : 100-202.

Purnamasari, S. A. Ayuni, dan Ernawati. (2017). Pengaruh Investasi dan Tenaga Kerja terhadap Pertumbuhan Ekonomi di Provinsi Sulawesi Tenggara. 2. Jurnal Progres Ekonomi Pembangunan. Vol 2, No 2. 2017. Hal. 1- 14. e-ISSN: 2052-5171

Riyanto dan H. Siregar. (2005). Dampak Dana perimbangan terhadap perekonomian daerah dan pemretaan antar Wilayah. Jurnal Kebijakan Ekonomi, I(1): 15-35.

Siahaan, F.Christine, dan R.V. Salomo. (2012). Alokasi Anggaran Belanja Sektor Transportasi dalam Anggaran Pendapatan dan Belanja Daerah Kota Depok tahun Anggaran 20062010. Jurnal Transportasi Vol 12 No. 1 April 2012: 21-32.

Sodik, J. dan D. Nuryadin. (2008). Determinasi Investasi di Daerah. Studi Kasus Provinsi di Indonesia. Jurnal Ekonomi Pembangunan, 13 ( 1): 15-31.

Suselo. S. Liani, Hilde Dameria Sihaloho, dan Tarsidin, (2008). Pengaruh Volatilitas Nilai Tukar terhadap Pertumbuhan Ekonomi Indonesia. Buletin Ekonomi Moneter dan Perbankan, Januari 181-220.

Todaro, M. dan Smith, S.C. (2006). Economic Development, Ninth Edition. Addison Wesley Harlow, Boston.

Wahyudin D dan Y. Imamudin. (2013). Determinan Pertumbuhan Ekonomi di Daerah Istimewa Yogyakarta. Jurnal Ekonomi dan Studi Pembangunan. Vol 14 Nomor 2. Oktober 2013 Hal. 120-126.

Wahyuni, I. S. Made, dan Y. Nyoman. (2014). Pengaruh Pengeluaran Pemerintah dan Investasi terhadap Pertumbuhan Ekonomi dan Kesenjangan Pendapatan Kabupaten/Kota di Provinsi Bali. E-Jurnal Ekonomi dan Bisnis Universitas Udayana hal. :458-477 ISSN : 2337-3067

Undang-Undang Nomor: 25 tahun 2004 tentang System Perencanaan Pembangunan Nasional

Undang-Undang Nomor :23 Tahun 2014 tentang Pemerintahan Daerah

Undang-Undang Nomor :33 Tahun 2004 tentang Perimbangan Keuangan antara Pemerintah Pusat dan Pemerintahan Daerah.

Peraturan Menteri Dalam Negeri Nomor: 13 Tahun 2006 tentang Pedoman Pengelolaan Keuangan Daerah 